\section{The influence of composition, microstructure and firing temperature on the density, porosity, and shrinkage of new zeolite-alumina composite material}

\author{
Jamal ELDIN F. M. IBRAHIM - Institute of Ceramics and Polymer Engineering, University of Miskolc, \\ Hungary - jamalfadoul@gmail.com \\ LÁszLó A. GÖMZE - Institute of Ceramics and Polymer Engineering, University of Miskolc, Hungary \\ - femgomze@uni-miskolc.hu
}

OLGA B. KOTOVA - Institute of Geology, Komi Science Center, Ural Branch of the Russian Academy of Sciences, Russian Federation - kotova@geo.komisc.ru

TATYANA N. SHCHEMELININA - Institute of Biology, Komi Science Center, Ural Branch of the Russian Academy of Sciences, Russian Federation - tatyanakomi@mail.ru

DMıтRY A. SHUSHKOV - Institute of Geology, Komi Science Center, Ural Branch of the Russian Academy of Sciences, Russian Federation • dashushkov@geo.komisc.ru

GRIGoRIY V. IGNATIEV - Institute of Geology, Komi Science Center, Ural Branch of the Russian Academy of Sciences, Russian Federation • ignatiev.grigoriy@gmail.com

ElenA M. ANCHUGOVA - Institute of Biology, Komi Science Center, Ural Branch of the Russian Academy of Sciences, Russian Federation - urosova@gmail.com

Érkezett: 2019. 06. 26. - Received: 26. 06. 2019. - https://doi.org/10.14382/epitoanyag-jsbcm.2019.21

\begin{abstract}
In this research work, new zeolite-alumina composite materials were prepared by mechanical activation and reactive sintering method. A detailed investigation of structure and microstructure of the raw materials and the produced ceramic samples have been precisely examined using X-ray diffraction (XRD) and scanning electron microscopy (SEM). Based on the raw material compositions, microstructure, and firing temperature, different characteristics were examined including, density, shrinkage, porosity and water absorption. The authors have found that the compositions and the firing temperature play a major role in the microstructure and the properties of the final product.

Keywords: zeolite-alumina ceramics, composite materials, mechanical activation, reactive sintering

Kulcsszavak: zeolit-alumínium-oxid kerámia, kompozit anyagok, mechanikai aktiválás, reaktív szinterezés.
\end{abstract}

\section{Introduction}

The research work in the field of ceramics technologies has been highly grown in the recent years [1-34]. Among ceramics materials, zeolites which represent a class of crystalline minerals have been highly utilized in a wide range of applications including chemical and petrochemical industries for catalysis, adsorption and the elimination of heavy metal ions from industrial wastewaters. Zeolites offer fascinating properties like high surface area, ion-exchange capacity, high adsorption efficiency and the ability to act as a host in preparation of nanocomposite materials [35]. These outstanding characteristics assigned to the unique structure of zeolites which contain a large number of uniformly distributed micropores. The research work in zeolite is motived not only by the need to synthesise new materials with expected potential applications [36]. But also the necessity to understand the formation of these interesting materials and to control their microstructure [37]. Zeolite-based composite materials have attracted a great deal of interest as technical materials due to
Jamal Eldin F. M. IBRAHIM is a lecturer in the University of Bahri, Khartoum, Sudan, he graduated from University of Marmara Istanbul, Turkey, Institute of Pure and Applied

Sciences, Department of Metallurgical and Materials Engineering, for the time being, he is a PhD student in the University of Miskolc, Institute of Polymer and Ceramics Engineering, under supervision of Prof. L. A. Gömze.

László A. GöMZE is establisher and professor of the Department of Ceramics and Silicate Engineering in the University of Miskolc. Hungary. He is author or co-author of 2 patents, 6 books and more than 300 scientific papers.

Olga B. KOTOVA

is professor and Head of Laboratory of Technology of Mineral Raw, Institute of Geology, Komi Science Center, Ural Branch of the Russian Academy of Sciences. Author and co-author of 4 patents and more than 150 scientific articles. Vice-president of International Commission on Applied Mineralogy (IMA-ICAM). Member of Russian Mineralogical Society.

Tatyana N. SHCHEMELININA is a researcher and head of research group at the Institute of Biology of Komi Science Center, Ural Branch of the Russian Academy of Sciences. She is author or co-author of several scientific papers both in English and Russian languages.

Dmitry A. SHUSHKOV Researcher of Laboratory of Technology of Mineral Raw, Institute of Geology, Komi Science Center, Ural Branch of the Russian Academy of Sciences. Author and co-author of 2 patents and more than 40 scientific articles. Russian Mineralogical Society.

Grigoriy V. IGNATIEV Junior researcher of Laboratory of Chemistry of Mineral Raw, Institute of Geology, Komi Science Center, Ural Branch of the Russian Academy of Sciences. He actually continues his studies as PhD student.

Elena M. ANCHUGOVA is a researcher at the Institute of Biology of Komi Science Center, Ural Branch of the Russian Academy of Sciences. She is author or co-author more than 10 scientific papers both in English and Russian languages.

the interesting complex composition and good mechanical behaviour [38]. Despite the huge research works conducted on zeolite-based composite materials [39-43], view previous works have been conducted concerning the influence of ceramic reinforcement in zeolite-based ceramic composite [44-46].

In this research study, zeolite-based Alumina ceramic composite materials were produced through mechanical activation and reactive sintering technique. The structure and microstructure of the raw materials and the final product have been investigated via X-ray diffraction (XRD) and scanning electron microscopy (SEM), moreover, the effect of composition, firing temperature on the density, porosity, and shrinkage was studied. These new zeolite-alumina mixtures 
which relatively inexpensive materials could be a potential candidate for many technical applications showing better properties.

\section{Experimental method}

\subsection{Synthesis of Zeolite - alumina composite materials}

Zeolite-based alumina composite ceramic materials were prepared through the mechanical activation and reactive sintering method. Zeolite powders from Tokaj region (Hungary) and $\mathrm{Al}_{2} \mathrm{O}_{3}$ powder (98 \%; MOTIM) were used as raw materials. An appropriate amount of these ceramic powders was carefully weighted using different compositions as shown in Table 1, then the prepared mixtures were milled and mixed in Retsch PM 400 planetary ball mill for 15 minutes in $150 \mathrm{rpm}$ using silica balls. The milled powders then used to make cylindrical discs with a diameter about $25 \mathrm{~mm}$ and thickness of $10 \mathrm{~mm}$ using uniaxial pressing machines under a pressure of $500 \mathrm{MPa}$. The prepared specimens were sintered at different temperatures $\left(1100^{\circ} \mathrm{C}, 1150^{\circ} \mathrm{C}, 1200^{\circ} \mathrm{C}\right.$ and $\left.1250^{\circ} \mathrm{C}\right)$ in a programmable furnace for $3 \mathrm{~h}$, with a heating rate of 60 ${ }^{\circ} \mathrm{C} / \mathrm{h}$.

\begin{tabular}{cc} 
Zeolite $\%$ & Alumina $\%$ \\
\hline 100 & 0 \\
\hline 90 & 10 \\
\hline 80 & 20 \\
\hline 70 & 30 \\
\hline 60 & 40 \\
\hline 50 & 50 \\
\hline
\end{tabular}

Table 1 The composition of the raw materials used to prepare the mixture 1. táblázat Azalapanyagokból készített keverékek összetétele

\subsection{Characterization}

The raw materials were characterized by Rigaku Miniflex II $\mathrm{X}$-ray diffractometer (XRD) operated in the Bragg-Brentano geometry and the samples were scanned between $2 \theta$ of $0-70^{\circ}$ with a scanning rate of $1 \% \mathrm{~min}$ and a step size of $0.01016^{\circ}$ using CuKa radiation $(\lambda=1.54184 \AA)$. For the computer-based investigation, DIFFRACT measurement software was used.

The topographical feature and the surface morphology of both raw materials and the prepared ceramic samples were examined using scanning electron microscopy (SEM) (Model TM-1000, HITACHI). The prepared samples were examined under several magnification values using secondary electrons.

\section{Results and discussion}

\subsection{Structures}

The relationship between the sintered temperatures and composition of the produced ceramics is shown in Fig. 1. It is well seen that using different sintering temperatures lead to varieties on the colour of the ceramic samples as well as differences on the shrinkage of the prepared discs. These could be attributed to the fact that above $1100^{\circ} \mathrm{C}$ zeolite starts to recrystallize and leads to physicochemical reactions which could highly affect the microstructure of the complex ceramics structure, as well as the properties.

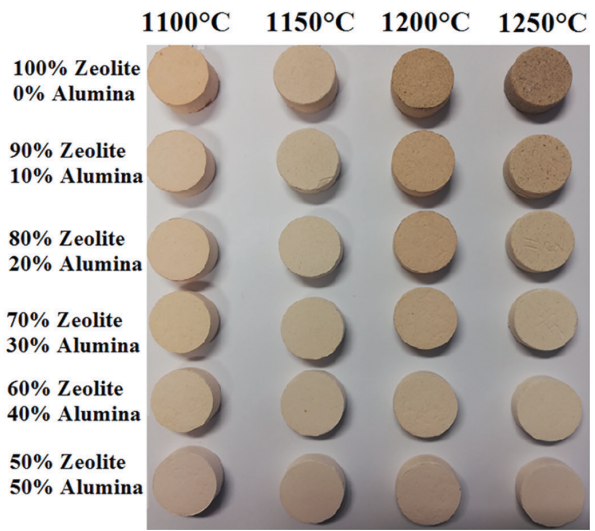

Fig. 1 Samples with different composition sintered at different temperature $\left(1100^{\circ} \mathrm{C}\right.$, $1150{ }^{\circ} \mathrm{C}, 1200^{\circ} \mathrm{C}$ and $1250^{\circ} \mathrm{C}$ )

1. ábra Az összetétel és az égetési hömérséklet $\left(1100^{\circ} \mathrm{C}, 1150^{\circ} \mathrm{C}, 1200^{\circ} \mathrm{C}\right.$ és $\left.1250^{\circ} \mathrm{C}\right)$ hatása a szinterelt zeolit mintákra

Fig. 2 exhibits the XRD pattern of natural zeolite. The analysis of the sample confirms the existence of different minerals, Table 2 reveals the chemical composition and the percentages of the different compounds.

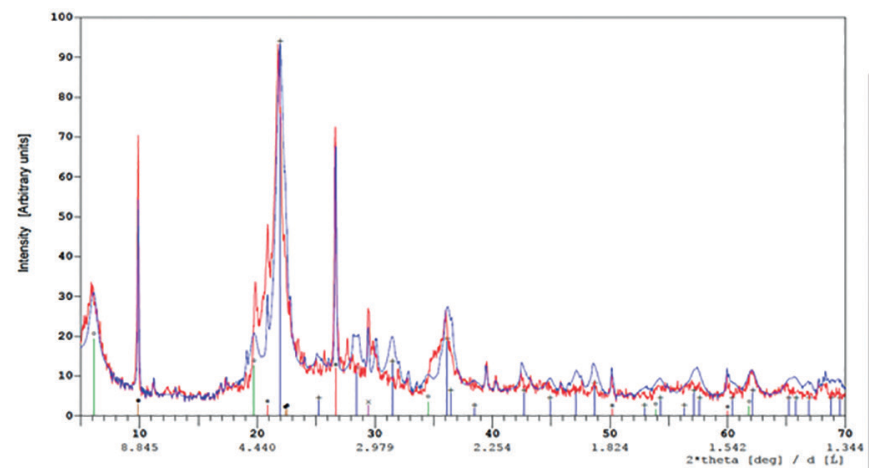

Fig. 2 XRD diffractogram of the natural Zeolite

2. ábra A természetes zeolit XRD diffraktogramja

\begin{tabular}{|c|c|c|c|c|c|c|}
\hline & Quartz & $\begin{array}{l}\text { Cristo- } \\
\text { balite }\end{array}$ & $\begin{array}{l}\text { Montmo- } \\
\text { rillonite }\end{array}$ & Calcite & $\begin{array}{c}\text { Clinopti- } \\
\text { Iolit }\end{array}$ & Total \\
\hline wt \% & 8.00 & 50.00 & 30.00 & 2.00 & 10.00 & 100.00 \\
\hline $\mathrm{CaO}$ & & & & 1.12 & & 1.12 \\
\hline $\mathrm{SiO}_{2}$ & 8.00 & 50.00 & 19.13 & & 5.79 & 82.92 \\
\hline $\mathrm{Al}_{2} \mathrm{O}_{3}$ & & & 4.06 & & 1.89 & 5.95 \\
\hline MgO & & & 3.21 & & & 3.21 \\
\hline $\mathrm{Na}_{2} \mathrm{O}$ & & & 0.74 & & 0.57 & 1.31 \\
\hline $\mathrm{CO}_{2}$ & & & & 0.88 & & 0.88 \\
\hline $\mathrm{H}_{2} \mathrm{O}$ & & & 2.87 & & 1.60 & 4.47 \\
\hline $\begin{array}{l}\text { Loss on } \\
\text { ignition }\end{array}$ & 0.00 & 0.00 & 2.87 & 0.88 & 1.75 & 5.50 \\
\hline
\end{tabular}

Table 2 Mineralogical constituents, chemical composition and loss on ignition (LOI) of the natural zeolite in $w t \%$, resulted from XRD analysis

2. táblázat A természetes zeolit ásványi XRD vizsgálata során megállapitott összetevői, kémiai összetétele és izzitási vesztesége (LOI) tömeg\%-ban

\subsection{SEM investigation of the raw materials}

Fig. 3 shows secondary electron images of the natural zeolite and alumina powders. The typical grains size of zeolite and alumina were found to be in the range of $0.5-25 \mu \mathrm{m}$ and 0.5 - 
$50 \mu \mathrm{m}$, respectively. While Fig. 4 shows the fractured surface of the produced ceramics samples ( $80 \%$ zeolite- $20 \%$ alumina) sintered at $1100{ }^{\circ} \mathrm{C}$ and $1200{ }^{\circ} \mathrm{C}$, it is clear that increasing the firing temperature leads to reduce the pores of the produced ceramics hence increase the density.

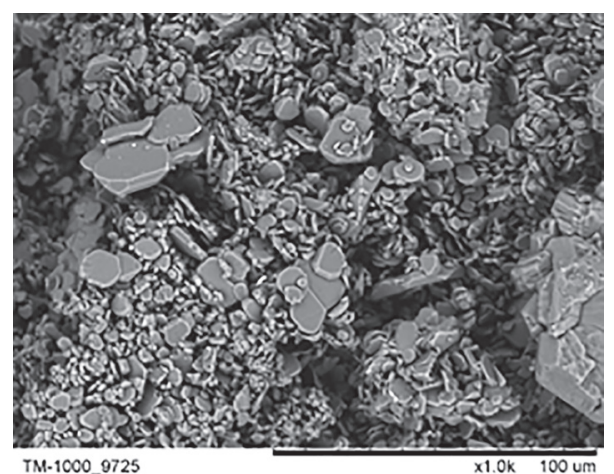

(a)

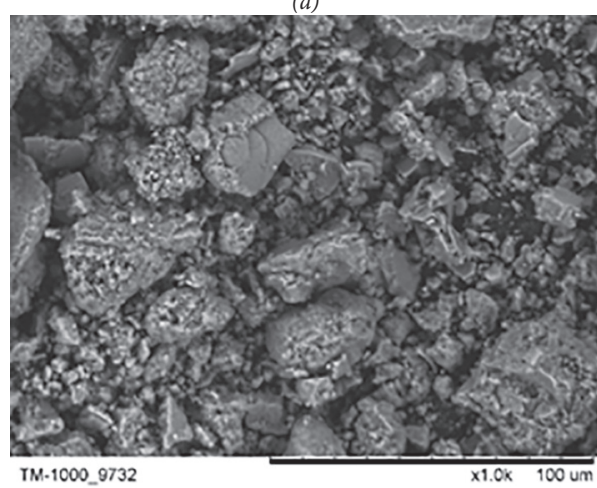

(b)

Fig. 3 SEM images of a) natural zeolite and $b$ ) alumina powders

3. ábra A természetes zeolit a) és az alumínium-oxid por b) mikroszerkezete (SEM)

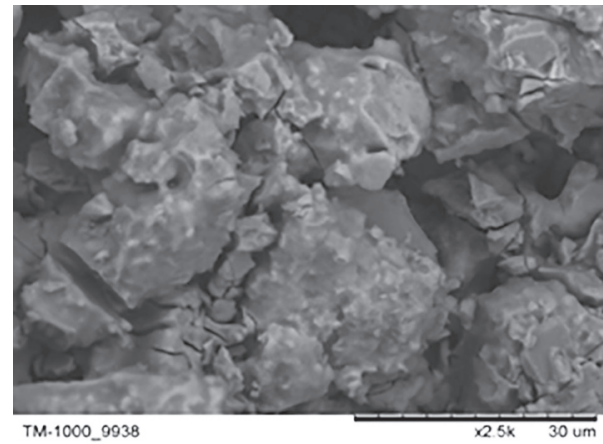

(a)

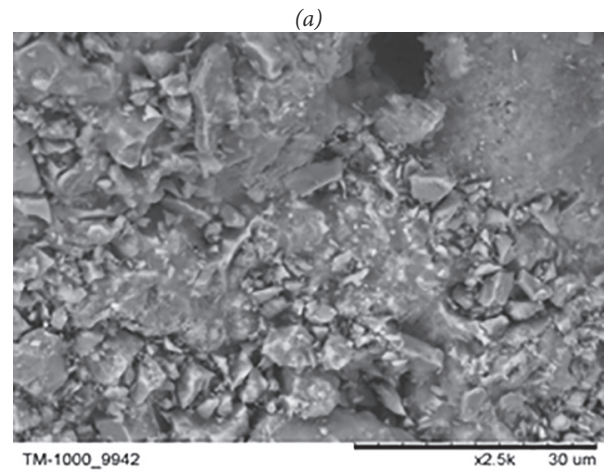

(b)

Fig. 4 SEM images of the fractured surface of $80 \%$ zeolite-20\% alumina sintered a) at $1100^{\circ} \mathrm{C}, b$ ) at $1200^{\circ} \mathrm{C}$

4. ábra Az $1100{ }^{\circ} \mathrm{C}$-on a) és $1200^{\circ} \mathrm{C}$-on b) szinterelt $80 \mathrm{~m} \%$ zeolit és $20 \mathrm{~m} \%$ aluminium-oxid felhasználásával készült minták töretfelülete (SEM)
The composition and sintering temperature show a substantial impact on the final density of sintered ceramic samples. The pure zeolite exhibits low density, this could be assigned to the highly porous structure of the zeolite. As the amount of alumina \% increasing, the density of the produced samples is gradually increased, likewise, increasing the sintering temperature also leads to increase in the density of the prepared discs, which also confirmed by SEM (Fig. 4). Pure zeolite sintered at $1100{ }^{\circ} \mathrm{C}$ offers the lowest density about $1.6 \mathrm{~g} / \mathrm{cm}^{3}$, on the other hand, $50 \%$ zeolite- $50 \%$ alumina samples sintered at $1250{ }^{\circ} \mathrm{C}$ displays the highest density of approximately $2 \mathrm{~g} / \mathrm{cm}^{3}$. The ffect of composition and sintering temperature is shown graphically in Fig. 5.

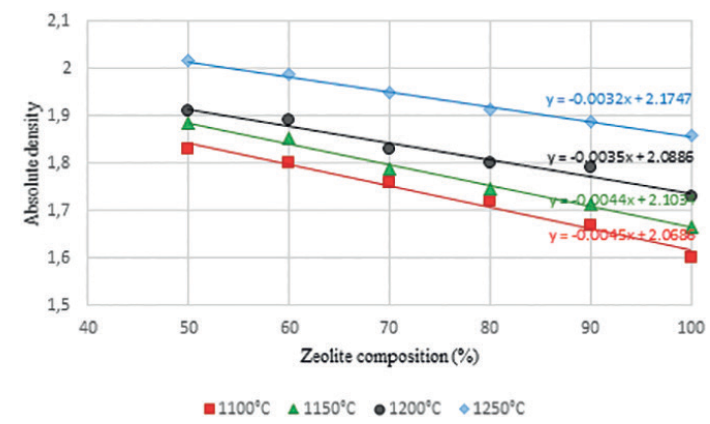

Fig. 5 The density of the zeolite-alumina samples sintered at different temperatures 5. ábra A különbözö hömérsékleteken szinterelt zeolit-aluminium-oxid minták sürüsége

The firing shrinkages of the produced specimens as a function of zeolite composition prepared at different sintering temperatures $\left(1100{ }^{\circ} \mathrm{C}, 1150{ }^{\circ} \mathrm{C}, 1200{ }^{\circ} \mathrm{C}\right.$ and $\left.1250{ }^{\circ} \mathrm{C}\right)$ are shown in Fig. 6. 50\% zeolite- 50\% alumina samples fired at $1100{ }^{\circ} \mathrm{C}$ exhibits the lowest shrinkage of approximately $5 \%$, with decreasing the \% of alumina in the sample, the firing shrinkage is progressively increased, furthermore, increasing the sintering temperature is highly increase the firing shrinkage. Pure zeolite sintered at $1250{ }^{\circ} \mathrm{C}$ shows the highest firing shrinkage about $23 \%$.

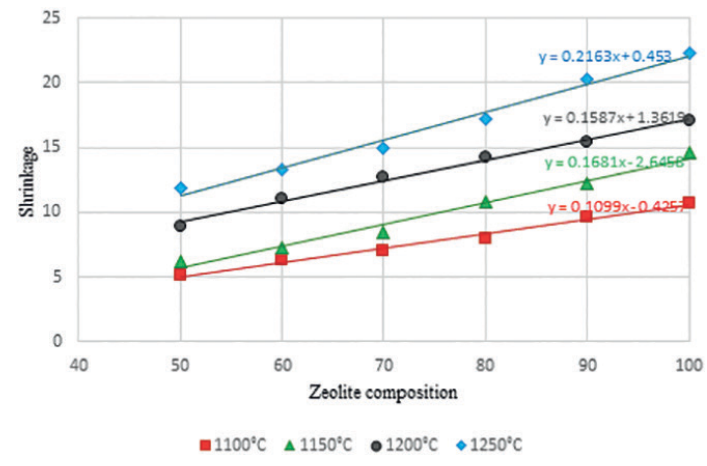

Fig. 6 The bulk shrinkage of the zeolite-alumina samples sintered at different temperatures

6. ábra A különböző hőmérsékleteken szinterelt zeolit-alumínium-oxid minták térfogati zsugorodása

Fig. 7 demonstrates the weight loss of the different composition of the zeolite-alumina samples sintered at variable temperatures, with increasing the sintering temperature from $1150{ }^{\circ} \mathrm{C}$ to $1250{ }^{\circ} \mathrm{C}$ the weight is highly increased from about $6 \%$ to more than $11 \%$. Pure Zeolite shows the highest weight loss. 


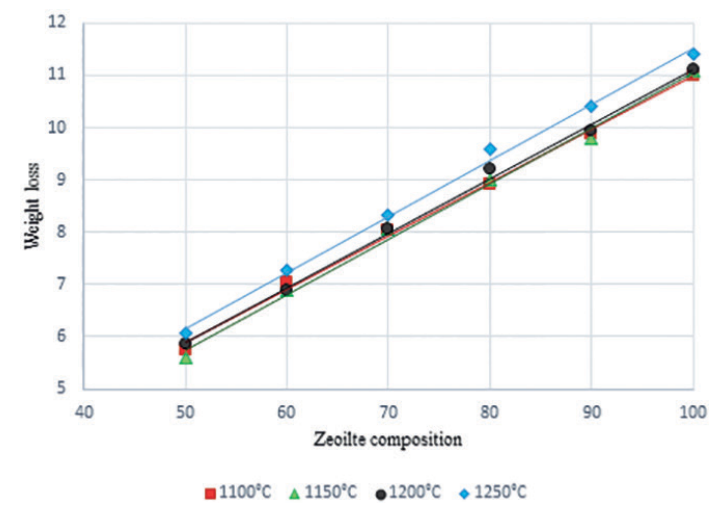

Fig. 7 The weight loss of the zeolite-alumina samples sintered at different temperatures

7. ábra A különbözö hömérsékleteken szinterelt zeolit-alumínium-oxid minták tömegvesztesége

Fig. 8 and 9 show the water absorption and apparent porosity of the prepared ceramic samples with different composition sintered in a range of temperature $\left(1100{ }^{\circ} \mathrm{C}, 1150{ }^{\circ} \mathrm{C}, 1200{ }^{\circ} \mathrm{C}\right.$ and $1250^{\circ} \mathrm{C}$ ) the two graphs are quite similar to each other, the two graphs exhibit low values of water absorption and apparent porosity when a large amount of zeolite and high sintering temperature are used.

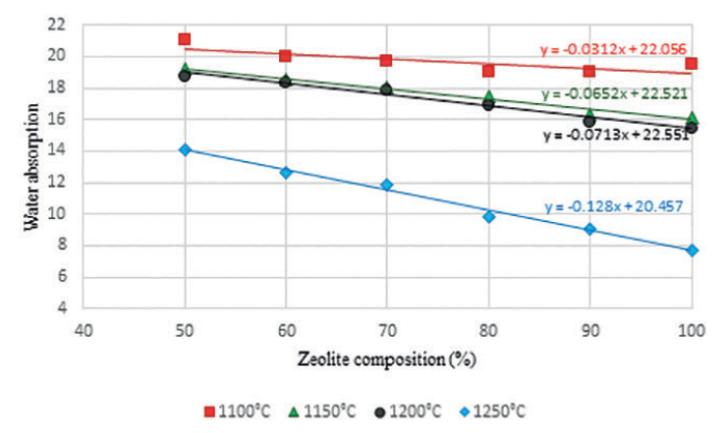

Fig. 8 The water absorption of the zeolite-alumina samples sintered at different temperatures

8. ábra A különböző hömérsékleteken szintereltt zeolit-alumínium-oxid minták vízfelvevö képessége

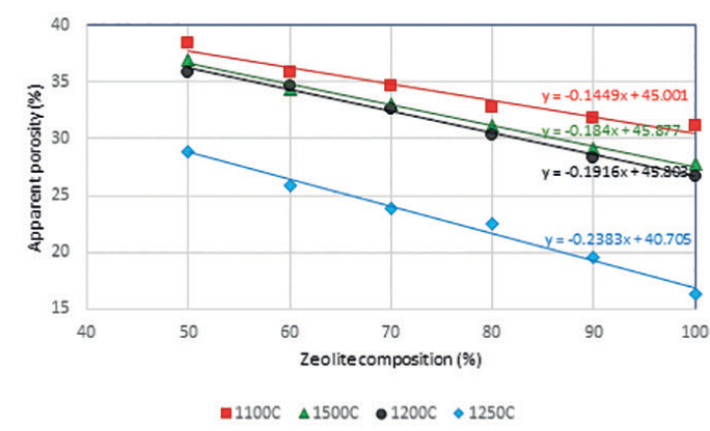

Fig. 9 The apparent porosity of the zeolite-alumina samples sintered at different temperatures

9. ábra A különböző hőmérsékleteken szinterelt zeolit-alumínium-oxid minták látszólagos porozitása

\section{Conclusion}

In conclusion, the important notice to be enlightened is that the composition and the firing temperature can highly influence the characteristics of the final ceramics products such as density, sintering weight loss, porosity and shrinkage. The data examined in this research work could be used to control the microstructure and, hence, the properties of sintered ceramic materials such as thermal conductivity, dilatation, thermal expansion coefficient, mechanical strength and other physical, chemical and mechanical properties.

\section{Acknowledgements}

The described study was carried out as part of the EFOP3.6.1-16-2016-00011 "Younger and Renewing University - Innovative Knowledge City - institutional development of the University of Miskolc aiming at intelligent specialisation" project implemented in the framework of the Szechenyi 2020 program. The realization of this project is supported by the European Union, co-financed by the European Social Fund.

\section{References}

[1] Kulkov, S.N. and Savchenko, N.L., 2008. Építőanyag - JSBCM 60(3), pp.62-65. http://dx.doi.org/10.14382/epitoanyag-jsbcm.2008.10

[2] Morikawa, A., Suzuki, T., Kikuta, K., Suda, A. and Shinjo, H., 2009. Építőanyag - JSBCM (1), p.2. http://dx.doi.org/10.14382/epitoanyag-jsbcm.2009.1

[3] Gömze, L.A. and Gömze, L.N., 2009. Építőanyag - JSBCM 61, pp.38-42. http://dx.doi.org/10.14382/epitoanyag-jsbcm.2009.7

[4] Ershova, N.I. and Kelina, I.Y., 2009. Építőanyag - JSBCM 61(2), pp.34-37. http://dx.doi.org/10.14382/epitoanyag-jsbcm.2009.6

[5] Miranda-Hernandez, J.G., La Torre, D., Diaz, S. and Rocha-Rangel, E., 2010. Építőanyag - JSBCM 61 (1), pp.1-5. http://dx.doi.org/10.14382/epitoanyag-jsbcm.2010.1

[6] Rocha-Rangel, E., Hernández-Silva, D., Terrés-Rojas, E., Martínez-Franco, E. and Díaz-De La Torre, S., 2010. Építőanyag - JSBCM 62 (3), p.75. http://dx.doi.org/10.14382/epitoanyag-jsbcm.2010.15

[7] Kuribayashi, K. and Ohmiya, D., 2010. Építőanyag - JSBCM 62(1), p.11. http://dx.doi.org/10.14382/epitoanyag-jsbcm.2010.3

[8] Khare, S., Sharma, M. and Venkateswarlu, K., 2010. Építőanyag JSBCM 62(2), p.39. http://dx.doi.org/10.14382/epitoanyag-jsbcm.2010.8

[9] Gömze, L.A. and Gömze, L.N., 2011. IOP Conf. Ser.: Mater. Sci. Eng. vol. 18, no. 8, p. 082001. https://doi.org/10.1088/1757-899X/18/8/082001

[10] Gömze, L.A. and Gömze, L.N., 2013. IOP Conf. Ser.: Mater. Sci. Eng. Vol. 47, No. 1, p. 012033. https://doi.org/10.1088/1757-899X/47/1/012033

[11] Kalatur, E.S., Kozlova, A.V., Buyakova, S.P. and Kulkov, S.N., 2013. IOP Conf. Ser.: Mater. Sci. Eng. Vol. 47, No. 1, p. 012004. https://doi.org/10.1088/1757-899X/47/1/012004

[12] Chu, H.L., Wang, C.L., Lee, H.E., Sie, Y.Y., Chen, R.S., Hwang, W.S., Wang, M.C. and Huang, H.H., 2013. Advanced Materials Research Vol. 749, pp. 44-48. https://doi.org/10.4028/www.scientific.net/AMR.749.44

[13] Mimira, T., Umeda, T., Musha, Y. and Itatani, K., 2013. IOP Conf. Ser.: Mater. Sci. Eng. Vol. 47, No. 1, p. 012008. https://doi.org/10.1088/1757-899X/47/1/012008

[14] Li, J., Yuan, W.J., Deng, C.J. and Zhu, H.X., 2013. IOP Conf. Ser.: Mater. Sci. Eng. Vol. 47, No. 1, p. 012060. https://doi.org/10.1088/1757-899X/47/1/012060

[15] Apkaryan, A.S., Kulkov, S.N. and Gömze, L.A., 2014. Építőanyag - JSBCM 66(2), pp.38-42. http://dx.doi.org/10.14382/epitoanyag-jsbcm.2014.8

[16] Ibrahim, Jamal Eldin. Enhancement of structural and magnetic properties of $\mathrm{Eu}$ and $\mathrm{Fe}$ doped $\mathrm{GdMnO}_{3}$ and $\mathrm{Cr}$ doped $\mathrm{HoMnO}_{3}$ multiferroic ceramics. diss. Marmara University, 2015. https://doi.org/10.13140/RG.2.2.32693.32486

[17] Gömze, L.A., 2016. Applied materials science II. Compilation of Selected Scientific Papers, pp.1-189. ISBN 978-963-12-6600-9.

[18] Szőke, A.M., Muntean, M., Sándor, M. and Brotea, L., 2016, IOP Conf. Ser.: Mater. Sci. Eng. Vol. 123, No. 1, p. 012043. https://doi.org/10.1088/1757-899X/123/1/012043

[19] Kurovics, E., Buzimov, A.Y. and Gömze, L.A., 2016, IOP Conf. Ser.: Mater. Sci. Eng. Vol. 123, No. 1, p. 012058. https://doi.org/10.1088/1757-899X/123/1/012058 
[20] Ayub, N. and Rafique, U., 2017. Építőanyag - JSBCM 69(3), pp.98-101. https://dx.doi.org/10.14382/epitoanyag-jsbcm.2017.17

[21] Kurovics, E., Shmakova, A., Kanev, B. and Gömze, L.A., 2017, IOP Conf. Ser.: Mater. Sci. Eng. Vol. 175, No. 1, p. 012013. https://doi.org/10.1088/1757-899X/175/1/012013

[22] Chuklina, S.G., Maslenkova, S.A., Pylinina, A.I., Podzorova, L.I. and Ilyicheva, A.A., 2017, IOP Conf. Ser.: Mater. Sci. Eng. Vol. 175, No. 1, p. 012031. https://doi.org/10.1088/1757-899X/175/1/012031

[23] Gömze, L.A. and Gömze, L.N., 2017. IOP Conf. Ser.: Mater. Sci. Eng. Vol. 175, No. 1, p. 012001. https://doi.org/10.1088/1757-899X/175/1/012001

[24] Buzimov, A.Y., Eckl, W., Gömze, L.A., Kocserha, I., Kurovics, E., Kulkov, A.S. and Kulkov, S.N., 2018. Építőanyag - JSBCM 70(1), pp.23-26. https://doi.org/10.14382/epitoanyag-jsbcm.2018.5

[25] Kracalik, M., 2018. Építőanyag - JSBCM 70(2), pp.42-47. https://doi.org/10.14382/epitoanyag-jsbcm.2018.9

[26] Gömze, L.A., Kulkov, S.N., Kurovics, E., Buyakov, A.S., Buzimov, A.Y., Grigoriev, M.V., Kanev, B.I., Kolmakova, T.V., Levkov, R.V. and Sitkevich, S.A., 2018. Építőanyag - JSBCM 70(1). https://doi.org/10.14382/epitoanyag-jsbcm.2018.3

[27] Buzimov, A.Y., Kulkov, S.N., Gömze, L.A., Géber, R. and Kocserha, I., 2018. Inorganic Materials: Applied Research, 9 (5), pp.910-915. https://doi.org/10.1134/S2075113318050040

[28] Knyazeva, A.G., Pribytkov, G.A. and Chumakov, Y.A., 2018. ÉpítőanyagJSBCM 70(3), pp.74-77.

https://doi.org/10.14382/epitoanyag-jsbcm.2018.13

[29] Lebedeva, N.N., Orbukh, V.I., Eyvazova, G.M., Darvishov, N.H. and Akhundov, C.G., 2018. Építőanyag - JSBCM 70 (4). https://doi.org/10.14382/epitoanyag-jsbcm.2018.22

[30] Baba, S., Goto, T., Cho, S. and Sekino, T., 2018. Építőanyag - JSBCM 70(6). https://doi.org/10.14382/epitoanyag-jsbcm.2018.34

[31] Ibrahim, J. E., - Mergen, A.: The Effect of Europium Doping on the Structural and Magnetic Properties of $\mathrm{GdMnO}_{3}$ Multiferroic Ceramics, Advanced Ceramics Progress, 3 (No. 4), 1-5, 2018. http://www.acerp.ir/Vol3/No4/1.pdf

[32] Penaloza Jr, D.P., 2019. Építőanyag - JSBCM 71(1). https://doi.org/10.14382/epitoanyag-jsbcm.2019.2

[33] Al-Mosawi, Ali I.Al-Maamori, Mohammed H.Marossy, Kalman, 2019. Építőanyag - JSBCM 71(2), pp 43-45. https://doi.org/10.14382/epitoanyag-jsbcm.2019.8

[34] Ibrahim, J. F. M., Kurovics, E. and Gömze, L. A. "Synthesis, characterization and rheological properties of alumina-zeolite mixtures. MultiScience XXXIII. microCAD International Multidisciplinary Scientific Conference, University of Miskolc, 23-24 May 2019, ISBN 978-963-358-177-3. https://doi.org/10.26649/musci.2019.076
[35] Xu, Ruren, et al. "Chemistry of zeolites and related porous materials: synthesis and structure". John Wiley \& Sons, 2009. ISBN ISBN 978-0-47082233-3.

[36] Davis, M.E., 2002. Nature, 417(6891), p.813. DOI: 10.1038/nature00785

[37] Morris, R.E., 2008. Elsevier, Vol. 174, pp. 33-42. https://doi.org/10.1016/S0167-2991(08)80149-8

[38] Smirniotis, P.G., Davydov, L.E.V. and Ruckenstein, E.L.I., 1999.Catalysis Reviews, 41(1), pp.43-113. https://doi.org/10.1081/CR-100101949

[39] Pino, L., Aristov, Y., Cacciola, G. and Restuccia, G., 1997. Adsorption, 3(1), pp.33-40. https://doi.org/10.1007/BF01133005

[40] Bauer, J., Herrmann, R., Mittelbach, W. and Schwieger, W. 2009. International Journal of Energy Research, 33(13), pp.1233-1249. https://doi.org/10.1002/er.1611

[41] Hongois, S., Kuznik, F., Stevens, P. and Roux, J.J., 2011. Development and characterisation of a new MgSO4- zeolite composite for long-term thermal energy storage. Solar Energy Materials and Solar Cells, 95(7), pp.1831-1837. https://doi.org/10.1016/j.solmat.2011.01.050

[42] Whiting, G.T., Grondin, D., Stosic, D., Bennici, S. and Auroux, A., 2014. Solar Energy Materials and Solar Cells, 128, pp.289-295. https://doi.org/10.1016/j.solmat.2014.05.016

[43] Kotova, O.B., Shabalin, I.L. and Kotova, E.L., 2016. Journal of Mining Institute, 220, pp.526-531. https://doi.org/10.18454/PMI.2016.4.526

[44] Chi, D.G. and Lee, H., WR Grace and Co, 1975. Alumina-zeolite composite adsorbents for refrigerants. U.S. Patent 3,899,310

[45] Nishiyama, N., Ueyama, K. and Matsukata, M., 1996. Elsevier 7(6), pp.299-308. https://doi.org/10.1016/S0927-6513(96)00053-3

[45] Basso, S., Tessonnier, J.P., Pham-Huu, C., Ledoux, M.J. and Wine, G., Centre National de la Recherche Scientifique CNRS, Universite Louis Pasteur (Strasbourg I) and SICAT, 2007. Zeolite/SiC composites and their use in catalysis. U.S. Patent 7,179,764.

Ref.:

Ibrahim, Jamal Eldin F. M. - Gömze, László A. - Kotova, Olga B. Shchemelinina, Tatyana N. - Shushkov, Dmitry A. - Ignatiev, Grigoriy V. - Anchugova, Elena M.: The influence of composition, microstructure and firing temperature on the density, porosity, and shrinkage of new zeolite-alumina composite material Építőanyag - Journal of Silicate Based and Composite Materials, Vol. 71, No. 4 (2019), 120-124. p. https://doi.org/10.14382/epitoanyag-jsbcm.2019.21

\section{European Composite Materials Congress}

Biosensors and Bioelectronic Materials Symposium Graphene and 2D Materials Conference
09 - 11 June 2020 | Stockholm, Sweden

Venue: M/S Mariella, Viking Line Cruise Ship

Stockholm (Sweden) - Helsinki (Finland) - Stockholm (Sweden)

The multi-inter-trans-disciplinary Research, Innovations and Technology 